\title{
Magnesium Sulphate for Fetal Neuroprotection
}

This clinical practice guideline has been prepared by the Guidelines Consensus Group, reviewed by the Maternal Fetal Medicine Committee, and approved by the Executive and Council of the Society of Obstetricians and Gynaecologists of Canada. This document has been reveiwed by the Fetus and Newborn Committee of the Canadian Paediatric Society.

\section{PRINCIPAL AUTHORS}

Laura Magee, MD, Vancouver BC

Diane Sawchuck, RN, PhD, Vancouver BC

Anne Synnes, MD, Vancouver BC

Peter von Dadelszen, MBChB, Vancouver BC

THE MAGNESIUM SULPHATE FOR FETAL NEUROPROTECTION CONSENSUS COMMITTEE

Melanie Basso, RN, Vancouver BC

Joan M. Crane, MD, St. John's NL

Lex Doyle, MD, Victoria, Australia

William Ehman, MD, Nanaimo BC

Robert Gagnon, MD, Montreal QC William Grobman, MD, Chicago IL Michael Helewa, MD, Winnipeg MB KS Joseph, MD, Vancouver BC Jocelyn Martel, MD, Saskatoon SK Steven Miller, MD, Vancouver BC Nan Okun, MD, Toronto ON

Dwight Rouse, MD, Providence RI

Vyta Senikas, MD, Ottawa ON

Rebecca Sherlock, MD, Vancouver BC

Amanda Skoll, MD, Vancouver BC

Graeme Smith, MD, Kingston ON

Brenda Wagner, MD, Richmond BC

Sandrine Wavrant, MD, Montreal QC

R. Douglas Wilson, MD, Calgary $A B$

Jennifer Hutcheon, $\mathrm{PhD}$, Vancouver BC

Key Words: Magnesium sulphate, preterm birth, cerebral palsy, death, neuroprotection

\author{
MATERNAL FETAL MEDICINE COMMITTEE \\ Robert Gagnon, MD (Co-Chair), Montreal QC \\ Lynda Hudon, MD (Co-Chair), Montreal QC \\ Melanie Basso, RN, Vancouver BC \\ Hayley Bos, MD, London ON \\ Joan M. Crane, MD, St. John's NL \\ Gregory Davies, MD, Kingston ON \\ Marie-France Delisle, MD, Vancouver BC \\ Savas Menticoglou, MD, Winnipeg MB \\ William Mundle, MD, Windsor ON \\ Annie Ouellet, MD, Sherbrooke QC \\ Tracy Pressey, MD, Vancouver BC \\ Christy Pylypjuk, MD, Saskatoon SK \\ Anne Roggensack, MD, Calgary AB \\ Frank L. Sanderson, MD, Saint John NB
}

Disclosure statements have been received from all members of the committees.

The literature searches and bibliographic support for this guideline were undertaken by Becky Skidmore, Medical Research Analyst, Society of Obstetricians and Gynaecologists of Canada.

\section{Abstract}

Objective: To provide guidelines for the use of antenatal magnesium sulphate $\left(\mathrm{MgSO}_{4}\right)$ for fetal neuroprotection of the preterm infant.

Options: Antenatal $\mathrm{MgSO}_{4}$ administration should be considered for fetal neuroprotection when women present at $\leq 31+6$ weeks with imminent preterm birth, defined as a high likelihood of birth because of active labour with cervical dilatation $\geq 4 \mathrm{~cm}$, with or without preterm pre-labour rupture of membranes, and/or planned preterm birth for fetal or maternal indications.

There are no other known fetal neuroprotective agents.

Outcomes: The outcomes measured are the incidence of cerebral palsy (CP) and neonatal death.

Evidence: Published literature was retrieved through searches of PubMed or Medline, CINAHL, and the Cochrane Library in May 2010, using appropriate controlled vocabulary and key words (magnesium sulphate, cerebral palsy, preterm birth). Results were restricted to systematic reviews, randomized controlled

This document reflects emerging clinical and scientific advances on the date issued, and is subject to change. The information should not be construed as dictating an exclusive course of treatment or procedure to be followed. Local institutions can dictate amendments to these opinions. They should be well documented if modified at the local level. None of these contents may be reproduced in any form without prior written permission of the SOGC. 
trials, and relevant observational studies. There were no date or language restrictions. Searches were updated on a regular basis and incorporated in the guideline to August 2010. Grey (unpublished) literature was identified through searching the websites of health technology assessment and health technology assessment-related agencies, clinical practice guideline collections, clinical trial registries, and national and international medical specialty societies.

Values: The quality of evidence was rated using the criteria described in the Report of the Canadian Task Force on Preventive Health Care (Table 1).

Benefits, harms, and costs: Antenatal magnesium sulphate for fetal neuroprotection reduces the risk of "death or CP" (RR 0.85; $95 \% \mathrm{Cl} 0.74$ to 0.98 ; 4 trials, 4446 infants), "death or moderatesevere CP" (RR $0.85 ; 95 \% \mathrm{Cl} 0.73$ to $0.99 ; 3$ trials, 4250 infants), "any CP" (RR $0.71 ; 95 \%$ Cl 0.55 to $0.91 ; 4$, trials, 4446 infants), "moderate-to-severe CP" (RR 0.60; $95 \% \mathrm{Cl} 0.43$ to $0.84 ; 3$ trials, 4250 infants), and "substantial gross motor dysfunction" (inability to walk without assistance) (RR $0.60 ; 95 \% \mathrm{Cl} 0.43$ to 0.83 ; 3 trials, 4287 women) at 2 years of age. Results were consistent between trials and across the meta-analyses. There is no anticipated significant increase in health care-related costs, because women eligible to receive antenatal $\mathrm{MgSO}_{4}$ will be judged to have imminent preterm birth.

Validation: Australian National Clinical Practice Guidelines were published in March 2010 by the Antenatal Magnesium Sulphate for Neuroprotection Guideline Development Panel. Antenatal $\mathrm{MgSO}_{4}$ was recommended for fetal neuroprotection in the same dosage as recommended in these guidelines. However, $\mathrm{MgSO}_{4}$ was recommended only at $<30$ weeks' gestation, based on 2 considerations. First, no one gestational age subgroup was considered to show a clear benefit. Second, in the face of uncertainty, the committee felt it was prudent to limit the impact of their clinical practice guidelines on resource allocation. Also in March 2010, the American College of Obstetricians and Gynecologists issued a Committee Opinion on $\mathrm{MgSO}_{4}$ for fetal neuroprotection. It stated that, "the available evidence suggests that magnesium sulphate given before anticipated early preterm birth reduces the risk of cerebral palsy in surviving infants." No official opinion was given on a gestational age cut-off, but it was recommended that physicians develop specific guidelines around the issues of inclusion criteria, dosage, concurrent tocolysis, and monitoring in accordance with one of the larger trials.

Sponsors: Canadian Institutes of Health Research (CIHR).

\section{Summary Statement}

1. "Imminent preterm birth" is defined as a high likelihood of birth due to one or both of the following conditions (II-2):

- Active labour with $\geq 4 \mathrm{~cm}$ of cervical dilation, with or without PPROM.

- Planned preterm birth for fetal or maternal indications.

\section{Recommendations}

1. For women with imminent preterm birth $(\leq 31+6$ weeks), antenatal magnesium sulphate administration should be considered for fetal neuroprotection. (I-A)

2. Although there is controversy about upper gestational age, antenatal magnesium sulphate for fetal neuroprotection should be considered from viability to $\leq 31+6$ weeks. (II-1B)

3. If antenatal magnesium sulphate has been started for fetal neuroprotection, tocolysis should be discontinued. (III-A)

4. Magnesium sulphate should be discontinued if delivery is no longer imminent or a maximum of 24 hours of therapy has been administered. (II-2B)

5. For women with imminent preterm birth, antenatal magnesium sulphate for fetal neuroprotection should be administered as a $4 \mathrm{~g}$ IV loading dose, over 30 minutes, followed by a $1 \mathrm{~g} / \mathrm{hr}$ maintenance infusion until birth. (II-2B)

6. For planned preterm birth for fetal or maternal indications, magnesium sulphate should be started, ideally within 4 hours before birth, as a $4 \mathrm{~g}$ IV loading dose, over 30 minutes, followed by a $1 \mathrm{~g} / \mathrm{hr}$ maintenance infusion until birth. (II-2B)

7. There is insufficient evidence that a repeat course of antenatal magnesium sulphate for fetal neuroprotection should be administered. (III-L)

8. Delivery should not be delayed in order to administer antenatal magnesium sulphate for fetal neuroprotection if there are maternal and/or fetal indications for emergency delivery. (III-E)

9. When magnesium sulphate is given for fetal neuroprotection, maternity care providers should use existing protocols to monitor women who are receiving magnesium sulphate for preeclampsia/ eclampsia. (III-A)

10. Indications for fetal heart rate monitoring in women receiving antenatal magnesium sulphate for neuroprotection should follow the fetal surveillance recommendations of the SOGC 2007 Fetal Health Surveillance: Antepartum and Intrapartum Consensus Guideline. (III-A)

11. Since magnesium sulphate has the potential to alter the neonate's neurological evaluation, causing hypotonia or apnea, health care providers caring for the neonate should have an increased awareness of this effect. (III-C)

J Obstet Gynaecol Can 2011;33(5):516-529

\section{BACKGROUND}

\section{ABBREVIATIONS}

$\mathrm{APH}$ antepartum hemorrhage

$\mathrm{CP}$ cerebral palsy

IQR interquartile range

IUGR intrauterine growth restriction

NNT number needed to treat

PPROM preterm pre-labour rupture of membranes

PTL preterm labour

\section{The Importance of Preterm Birth}

The Canadian preterm birth rate overall reached $18.2 \%$ of live births in 2004, with births at $<32$ weeks representing $1.2 \%$ of live births in Canada. ${ }^{1}$ The survival of infants born preterm has improved with interventions such as antenatal corticosteroids and surfactant. However, survival has been associated with substantial risk of medical and neurodevelopmental impairment. 
Table 1. Key to evidence statements and grading of recommendations, using the ranking of the Canadian Task Force on Preventive Health Care

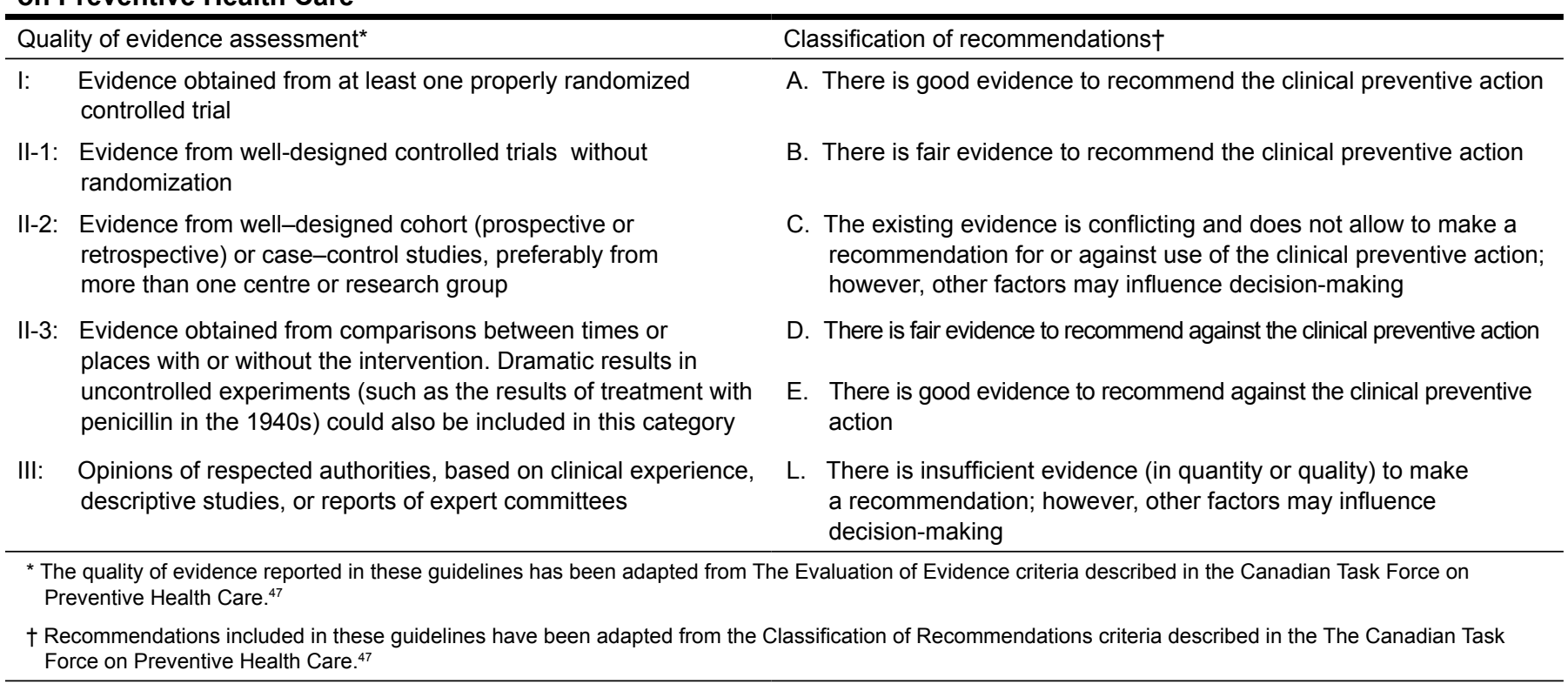

Two identified patterns of injury appear to underlie the central nervous system complications of preterm infants: (1) intraventricular hemorrhage and (2) white matter injury. Severe intraventricularhemorrhage (grades 3 and 4 ) is reliably detected by ultrasound and occurs primarily among babies who are born at or before 28 weeks' gestation. Although the incidence of severe intraventricular hemorrhage is highest at 24 to 25 weeks, severe intraventricular hemorrhage is still a relevant problem up to 28 weeks, because there are more births at 26 to 28 weeks than at 24 to 25 weeks. MRI is required for reliable detection of white matter injury, which has a peak prevalence at 28 weeks. Its severity is associated with adverse motor and cognitive outcomes. ${ }^{2}$

Clinically, the most frequent adverse neurological outcomes associated with preterm birth are cerebral palsy and cognitive impairment. Other adverse outcomes include blindness, deafness, developmental delay, and/or other neurological impairment. More than $50 \%$ of very preterm babies suffer from learning or motor disabilities or school difficulties, compared with about $20 \%$ of normal birthweight controls. ${ }^{3}$

\section{The Importance of Cerebral Palsy}

Cerebral palsy is a symptom complex of non-progressive motor impairment syndromes secondary to brain injury or anomalies arising in early development. ${ }^{4}$ The typical signs of $\mathrm{CP}$ include spasticity, movement disorders, muscle weakness, ataxia, and rigidity. There are 4 main types of cerebral palsy:

1. Spastic (increased muscle tone)

2. Athetoid or dyskinetic (slow, uncontrolled movements)
3. Ataxic (problems with balance and depth perception) 4. Mixed

The most common pattern is spasticity plus athetoid movements. ${ }^{5} \mathrm{CP}$ can be reliably diagnosed by the age of 2 years.

The prevalence of $\mathrm{CP}$ is 2 to 2.5 per 1000 live births. ${ }^{6}$ The risk of $\mathrm{CP}$ is highest at earlier gestational ages. Compared with infants born at term, infants born preterm have a CP risk that is approximately 3 -fold higher at 34 to 36 weeks, ${ }^{7} 8$-fold ${ }^{7}$ to 14 -fold ${ }^{8}$ higher at 30 to 33 weeks, 46 -fold higher at 28 to 30 weeks, $^{8}$ and as high as 30 -fold ${ }^{4}$ to 80 -fold ${ }^{8}$ higher at $<28$ weeks. ${ }^{9}$ The gestational age-related risk is associated, in part, with very low birth weight (i.e., $<1500 \mathrm{~g}$ ) and intraventricular hemorrhage. ${ }^{10-12}$ Multiples are also at heightened CP risk. ${ }^{13}$

Temporal trends in the prevalence of CP among infants born very preterm are a matter of controversy. Rates have been reported to be both falling ${ }^{14,15}$ and rising, ${ }^{10,16}$ possibly because perinatal mortality rates are decreasing, so that the rate of "death or CP" among infants born at $<30$ weeks has appeared to be stable. ${ }^{6}$

What is agreed upon, however, is that the economic burden associated with CP is enormous. The US Centers for Disease Control and Prevention estimate that lifetime health care, productivity, and social costs for a person with CP are US $\$ 921000$ (2003). ${ }^{17}$

There is no known cure for $\mathrm{CP}$, which makes effective preventive measures of primary importance. To date, no 
Table 2. Inclusion criteria in the randomized controlled trials of magnesium sulphate for fetal neuroprotection

\begin{tabular}{|c|c|c|c|c|c|c|c|c|c|c|}
\hline \multirow[b]{2}{*}{ Study } & \multirow[b]{2}{*}{$\begin{array}{l}\text { Women, } \\
\mathrm{n}\end{array}$} & \multirow[b]{2}{*}{$\begin{array}{c}\text { Multiple } \\
\text { pregnancy, } \\
\%\end{array}$} & \multicolumn{8}{|c|}{ Inclusion criteria* } \\
\hline & & & $\begin{array}{l}\text { Gestational } \\
\text { age, weeks }\end{array}$ & $\begin{array}{l}\text { Delivery } \\
\text { likely within } \\
24 \text { hours }\end{array}$ & $\begin{array}{l}\text { PTL, } \\
\%\end{array}$ & PPROM & $\begin{array}{l}\text { Chorioam- } \\
\text { nionitis }\end{array}$ & $\begin{array}{c}\text { Pre- } \\
\text { eclampsia }\end{array}$ & $\begin{array}{l}\text { Severe } \\
\text { IUGR }\end{array}$ & $\mathrm{APH}$ \\
\hline \multicolumn{11}{|c|}{ Neuroprotective intent } \\
\hline $\begin{array}{l}\mathrm{ACTOMgSO}_{4} \\
\text { Crowther et al. } \\
2003^{35}\end{array}$ & 1062 & 17 & $<30$ & Yes & 63 & $9 \%$ & $14 \%$ & $15 \%$ & $9 \%$ & $14 \%$ \\
\hline $\begin{array}{l}\text { PREMAG Marrett } \\
\text { et al. } 2006^{36}\end{array}$ & 564 & 22 & $<33$ & Yes & 85 & $61 \%$ & $11 \%$ & Excluded & Excluded & $19 \%$ \\
\hline $\begin{array}{l}\text { MAGnet } \\
\text { Mittendorf et al. } \\
2002- \\
\text { neuroprotective } \\
\text { intent arm }{ }^{37}\end{array}$ & 57 & 4 & 25 to $33+6$ & NA & $100 \dagger$ & $\begin{array}{c}\text { If } \\
\text { associated } \\
\text { with PTL }\end{array}$ & Excluded & Excluded & NA & NA \\
\hline $\begin{array}{l}\text { BEAM Rouse } \\
\text { et al. } 2008^{38}\end{array}$ & 2241 & 9 & 24 to $31+6$ & NA & 10 & $87 \%$ & NA & Excluded & $\begin{array}{l}\text { Included } \\
\text { by } \% \text { NA }\end{array}$ & NA \\
\hline \multicolumn{11}{|c|}{ Other primary intent } \\
\hline $\begin{array}{l}\text { MAGnet Mittendorf } \\
\text { et al. 2002, tocolytic } \\
\text { arm }^{37}\end{array}$ & 92 & 15 & 25 to $33+6$ & NA & 100 & $\begin{array}{c}\text { If } \\
\text { associated } \\
\text { with PTL }\end{array}$ & Yesł & Excluded & NA & Yesł \\
\hline MAGPIE $2006^{41}$ & $\begin{array}{c}10 \\
141\end{array}$ & ges & $\begin{array}{l}<37 \\
\text { subgroup anal } \\
\text { e possible for lo } \\
\text { ional age categ }\end{array}$ & $\begin{array}{ll} & \text { NA } \\
\text { es } \\
\text { er } \\
\text { ies) }\end{array}$ & NA & NA & NA & $100 \%$ & NA & NA \\
\hline \multicolumn{11}{|c|}{ LD: loading dose; NA: not available } \\
\hline \multicolumn{11}{|c|}{ * indications for at least $90 \%$ of study population listed. } \\
\hline$\ddagger 71.1 \%$ had PPROM & $1.8 \%$ had & Jamnionitis & results w & esent & ngt & & & & & \\
\hline
\end{tabular}

antenatal interventions have been identified that effectively decrease CP risk among preterm infants.

\section{Magnesium Sulphate for Neuroprotection}

In two studies published in the 1980s, preterm infants born to women with preeclampsia had a lower incidence of adverse CNS outcomes than gestational age-matched neonates born to mothers without preeclampsia. ${ }^{18,19}$ In 1995, a seminal case-control study ${ }^{20}$ was conducted with data derived from the California Cerebral Palsy project. ${ }^{21}$ It demonstrated an association between antenatal magnesium sulphate administration prior to preterm birth and fewer cases of CP among infants born $<1500$ g. ${ }^{20}$ It has been proposed that use of magnesium sulphate for eclampsia treatment and prophylaxis may underlie the potential association between antenatal administration of magnesium sulphate and $\mathrm{CP},{ }^{20,22}$ but the findings of subsequent observational studies investigating the association have been inconsistent. ${ }^{23-25}$ Although the effectiveness of magnesium sulphate for prevention and treatment of maternal eclampsia is well proven, there remains a lack of understanding of how it may act as a neuroprotective agent. ${ }^{26,27}$ Magnesium acts in many intracellular processes, and its actions include cerebral vasodilation, reduction in inflammatory cytokines and/or oxygen free radicals, and/or inhibition of calcium influx into cells. ${ }^{28,29}$ Animal studies have shown a neuroprotective effect. $^{30,31}$

From 2002 to 2008, 5 randomized controlled trials (6145 babies) studied magnesium sulphate for fetal neuroprotection (Table 2). In 2009, a milestone was reached with the publication of 3 meta-analyses, all of which concluded that magnesium sulphate for fetal neuroprotection decreases the risk of childhood CP. ${ }^{32-34}$ Four trials used magnesium sulphate specifically for fetal neuroprotection among women likely to deliver within 24 hours. ${ }^{35-38}$ The fifth trial ${ }^{26}$ evaluated the effectiveness of magnesium sulphate for eclampsia prevention in women with preeclampsia. Of the 4 trials with neuroprotective intent, one also included a tocolytic arm. ${ }^{37}$ Three of these 4 trials enrolled primarily women with preterm labour (with or without PPROM), ${ }^{35-37}$ whereas the fourth focused on women with PPROM. ${ }^{38}$ Children were followed-up to the age of 2 years for CP assessment, and 3 trials undertook cognitive testing. ${ }^{26,35,38}$

Study quality was good. ${ }^{32}$ Importantly, 4 of the 5 trials (and all neuroprotective intent trials) described an adequate 
Table 3a. Magnesium sulphate versus placebo: perinatal outcomes in neuroprotection trials only

\begin{tabular}{|c|c|c|c|c|c|c|}
\hline & \multicolumn{3}{|c|}{$\mathrm{RR}(95 \% \mathrm{Cl})$} & \multicolumn{3}{|c|}{ Trials, n, Infants, $\mathrm{n}$} \\
\hline & Doyle et al. ${ }^{34}$ & $\begin{array}{l}\text { Costantine } \\
\text { and Weiner }{ }^{33}\end{array}$ & $\begin{array}{l}\text { Conde-Agudelo } \\
\text { and Romero }{ }^{32}\end{array}$ & Doyle et al. ${ }^{34}$ & $\begin{array}{c}\text { Costantine } \\
\text { and Weiner }{ }^{33}\end{array}$ & $\begin{array}{l}\text { Conde-Agudelo } \\
\text { and Romero }{ }^{32}\end{array}$ \\
\hline \multicolumn{7}{|c|}{ Primary outcomes } \\
\hline Death or $\mathrm{CP}$ & $\begin{array}{c}0.85 \\
(0.74 \text { to } 0.98)\end{array}$ & $\begin{array}{c}0.86 \\
(0.75 \text { to } 0.99)\end{array}$ & Not presented & $\begin{array}{c}4 \text { trials, } \\
4446 \text { infants }\end{array}$ & $\begin{array}{c}4 \text { trials, } \\
4314 \text { infants }\end{array}$ & Not presented \\
\hline $\begin{array}{l}\text { Death or moderate- } \\
\text { severe CP }\end{array}$ & & $\begin{array}{c}0.85 \\
(0.73 \text { to } 0.99)\end{array}$ & Not presented & Not presented & $\begin{array}{c}3 \text { trials, } \\
4250 \text { infants }\end{array}$ & Not presented \\
\hline $\begin{array}{l}\text { Death or substantial } \\
\text { gross motor dysfunction }\end{array}$ & $\begin{array}{c}0.84 \\
(0.71 \text { to } 1.00)\end{array}$ & Not presented & Not presented & $\begin{array}{c}3 \text { trials, } \\
4387 \text { infants }\end{array}$ & Not presented & Not presented \\
\hline Death & $\begin{array}{c}0.95 \\
(0.80 \text { to } 1.12)\end{array}$ & $\begin{array}{c}0.95 \\
(0.80 \text { to } 1.13)\end{array}$ & $\begin{array}{c}0.95 \\
(0.80 \text { to } 1.12)\end{array}$ & $\begin{array}{c}4 \text { trials, } \\
4446 \text { infants }\end{array}$ & $\begin{array}{c}4 \text { trials, } \\
4324 \text { infants }\end{array}$ & $\begin{array}{c}4 \text { trials, } \\
4446 \text { infants }\end{array}$ \\
\hline $\mathrm{CP}$ & $\begin{array}{c}0.71 \\
(0.55 \text { to } 0.91)\end{array}$ & $\begin{array}{c}0.71 \\
(0.55 \text { to } 0.91)\end{array}$ & $\begin{array}{c}0.71 \\
(0.55 \text { to } 0.91)\end{array}$ & $\begin{array}{c}4 \text { trials, } \\
4446 \text { infants }\end{array}$ & $\begin{array}{c}4 \text { trials, } \\
4314 \text { infants }\end{array}$ & $\begin{array}{c}4 \text { trials, } \\
4446 \text { infants }\end{array}$ \\
\hline Moderate-severe CP & Not presented & $\begin{array}{c}0.60 \\
(0.43 \text { to } 0.84)\end{array}$ & Not presented & Not presented & $\begin{array}{c}3 \text { trials, } \\
4250 \text { infants }\end{array}$ & Not presented \\
\hline $\begin{array}{l}\text { Substantial gross motor } \\
\text { dysfunction }\end{array}$ & $\begin{array}{c}0.60 \\
(0.43 \text { to } 0.83)\end{array}$ & Not presented & Not presented & $\begin{array}{c}3 \text { trials; } \\
4387 \text { infants }\end{array}$ & Not presented & Not presented \\
\hline $\begin{array}{l}\text { Any neurological } \\
\text { impairment }\end{array}$ & $\begin{array}{c}1.03 \\
(0.87 \text { to } 1.21)\end{array}$ & Not presented & Not presented & $\begin{array}{c}1 \text { trial, } \\
1255 \text { infants }\end{array}$ & Not presented & Not presented \\
\hline \multicolumn{7}{|c|}{ Other neonatal CNS outcomes } \\
\hline IVH & $\begin{array}{c}0.96 \\
(0.86 \text { to } 1.07)\end{array}$ & Not presented & Not presented & $\begin{array}{c}4 \text { trials to } \\
4446 \text { infants }\end{array}$ & Not presented & Not presented \\
\hline $\begin{array}{l}\text { Severe IVH } \\
\text { (grade } 3 \text { or } 4 \text { ) }\end{array}$ & $\begin{array}{c}0.83 \\
(0.62 \text { to } 1.13)\end{array}$ & Not presented & Not presented & $\begin{array}{c}2 \text { trials; } \\
3699 \text { infants }\end{array}$ & Not presented & Not presented \\
\hline PVL & $\begin{array}{c}0.93 \\
(0.68 \text { to } 1.28)\end{array}$ & Not presented & Not presented & $\begin{array}{c}4 \text { trials to } \\
4446 \text { infants }\end{array}$ & Not presented & Not presented \\
\hline \multicolumn{7}{|c|}{ Other infant/child neurodevelopmental outcomes } \\
\hline $\begin{array}{l}\text { Developmental delay or } \\
\text { intellectual impairment }\end{array}$ & $\begin{array}{c}1.00 \\
\text { (0.91 to } 1.09)\end{array}$ & Not presented & Not presented & $\begin{array}{c}3 \text { trials, } \\
4387 \text { infants }\end{array}$ & Not presented & Not presented \\
\hline $\begin{array}{l}\text { Major neurological } \\
\text { disability }\end{array}$ & $\begin{array}{c}1.14 \\
(0.86 \text { to } 1.51)\end{array}$ & Not presented & $\begin{array}{c}1.09 \\
(0.83 \text { to } 1.43)\end{array}$ & $\begin{array}{c}1 \text { trial, } \\
1255 \text { infants }\end{array}$ & Not presented & $\begin{array}{l}2 \text { trials, } \\
2060 \text { infants }\end{array}$ \\
\hline Blindness & $\begin{array}{c}0.97 \\
(0.14 \text { to } 6.90)\end{array}$ & Not presented & $\begin{array}{c}0.97 \\
(0.14 \text { to } 6.90)\end{array}$ & $\begin{array}{c}2 \text { trials, } \\
1943 \text { infants }\end{array}$ & Not presented & $\begin{array}{l}2 \text { trials, } \\
1943 \text { infants }\end{array}$ \\
\hline Deafness & $\begin{array}{c}0.51 \\
(0.05 \text { to } 4.96)\end{array}$ & Not presented & $\begin{array}{c}0.51 \\
(0.05 \text { to } 4.96)\end{array}$ & $\begin{array}{c}2 \text { trials, } \\
1943 \text { infants }\end{array}$ & Not presented & $\begin{array}{c}2 \text { trials, } \\
1943 \text { infants }\end{array}$ \\
\hline
\end{tabular}

method of allocation concealment. ${ }^{26,35,36,38}$ All but the tocolytic arm of Mittendorf et al. ${ }^{37}$ described doublemasking of outcome assessment.

\section{Magnesium Sulphate Use in Obstetrics}

Magnesium sulphate is widely available and commonly used in Canadian obstetric practice for eclampsia prophylaxis and treatment. ${ }^{26,27,39}$ Magnesium sulphate is no longer recommended for tocolysis, because it is ineffective. ${ }^{34}$

This document summarizes the relevant evidence and provides practice recommendations related to the use of antenatal magnesium sulphate for fetal neuroprotection among women with imminent preterm birth.

\section{Summary Statement}

1. "Imminent preterm birth" is defined as a high likelihood of birth due to one or both of the following conditions (II-2):
- Active labour with $\geq 4 \mathrm{~cm}$ of cervical dilation, with or without PPROM.

- Planned preterm birth for fetal or maternal indications.

\section{Recommendation}

1. For women with imminent preterm birth ( $\leq 31+6$ weeks), antenatal magnesium sulphate administration should be considered for fetal neuroprotection. (I-A)

Table 3 a presents the results of the 3 relevant metaanalyses of neuroprotective trials, ${ }^{32-34}$ and shows that antenatal magnesi um sulphate reduced the risk of "death or CP," "death or moderate-severe CP," "any CP," 
Table 3b. Magnesium sulphate versus placebo: perinatal outcomes in all trials of antenatal magnesium sulphate

\begin{tabular}{|c|c|c|c|c|c|c|}
\hline & \multicolumn{2}{|c|}{ Doyle et al. ${ }^{34}$} & \multicolumn{2}{|c|}{ Costantine and Weiner ${ }^{33}$} & \multicolumn{2}{|c|}{ Conde-Agudelo and Romero ${ }^{32}$} \\
\hline & $\operatorname{RR}(95 \% \mathrm{Cl})$ & $\begin{array}{l}\text { Trials, } \mathrm{n} \\
\text { Infants, } \mathrm{n}\end{array}$ & $\mathrm{RR}(95 \% \mathrm{Cl})$ & $\begin{array}{l}\text { Trials, } \mathrm{n} \\
\text { Infants } \mathrm{n}\end{array}$ & $\operatorname{RR}(95 \% \mathrm{Cl})$ & $\begin{array}{l}\text { Trials, } \mathrm{n} \\
\text { Infants } \mathrm{n}\end{array}$ \\
\hline \multicolumn{7}{|c|}{ Primary outcomes } \\
\hline Death or CP & $\begin{array}{c}0.94 \\
(0.78 \text { to } 1.12)\end{array}$ & $\begin{array}{l}5 \text { trials, } \\
6145 \text { infants }\end{array}$ & $\begin{array}{c}0.92 \\
(0.83 \text { to } 1.03)\end{array}$ & $\begin{array}{c}5 \text { trials, } \\
5225 \text { infants }\end{array}$ & $\begin{array}{c}0.92 \\
(0.83 \text { to } 1.02)\end{array}$ & $\begin{array}{c}5 \text { trials, } \\
5357 \text { infants }\end{array}$ \\
\hline $\begin{array}{l}\text { Death or moderate- } \\
\text { severe CP }\end{array}$ & Not presented & Not presented & $\begin{array}{c}0.85 \\
(0.73 \text { to } 0.99)\end{array}$ & $\begin{array}{c}3 \text { trials, } \\
4250 \text { infants }\end{array}$ & Not presented & Not presented \\
\hline $\begin{array}{l}\text { Death or substantial } \\
\text { gross motor dysfunction }\end{array}$ & $\begin{array}{c}0.92 \\
(0.75 \text { to } 1.12)\end{array}$ & $\begin{array}{c}4 \text { trials, } \\
5980 \text { infants }\end{array}$ & Not presented & Not presented & Not presented & Not presented \\
\hline Death & $\begin{array}{c}1.01 \\
(0.82 \text { to } 1.23)\end{array}$ & $\begin{array}{c}5 \text { trials, } \\
6145 \text { infants }\end{array}$ & $\begin{array}{c}0.95 \\
(0.80 \text { to } 1.13)\end{array}$ & $\begin{array}{c}4 \text { trials, } \\
4324 \text { infants }\end{array}$ & $\begin{array}{c}1.01 \\
(0.89 \text { to } 1.14)\end{array}$ & $\begin{array}{c}5 \text { trials, } \\
5357 \text { infants }\end{array}$ \\
\hline $\mathrm{CP}$ & $\begin{array}{c}0.69 \\
(0.54 \text { to } 0.87)\end{array}$ & $\begin{array}{c}5 \text { trials, } \\
6145 \text { infants }\end{array}$ & $\begin{array}{c}0.71 \\
(0.55 \text { to } 0.91)\end{array}$ & $\begin{array}{c}4 \text { trials, } \\
4314 \text { infants }\end{array}$ & $\begin{array}{c}0.69 \\
(0.55 \text { to } 0.88)\end{array}$ & $\begin{array}{c}5 \text { trials, } \\
5357 \text { infants }\end{array}$ \\
\hline Moderate-severe CP & Not presented & Not presented & $\begin{array}{c}0.60 \\
(0.43 \text { to } 0.84)\end{array}$ & $\begin{array}{c}3 \text { trials, } \\
4250 \text { infants }\end{array}$ & $\begin{array}{c}0.64 \\
(0.44 \text { to } 0.92)\end{array}$ & $\begin{array}{c}3 \text { trials, } \\
4387 \text { infants }\end{array}$ \\
\hline $\begin{array}{l}\text { Substantial gross motor } \\
\text { dysfunction }\end{array}$ & $\begin{array}{c}0.60 \\
(0.43 \text { to } 0.83)\end{array}$ & $\begin{array}{c}4 \text { trials, } \\
4387 \text { infants }\end{array}$ & Not presented & Not presented & $\begin{array}{c}0.60 \\
(0.43 \text { to } 0.83)\end{array}$ & $\begin{array}{c}3 \text { trials, } \\
4387 \text { infants }\end{array}$ \\
\hline $\begin{array}{l}\text { Any neurological } \\
\text { impairment }\end{array}$ & $\begin{array}{c}1.01 \\
(0.86 \text { to } 1.19)\end{array}$ & $\begin{array}{c}2 \text { trials, } \\
2848 \text { infants }\end{array}$ & Not presented & Not presented & $\begin{array}{c}1.02 \\
(0.86 \text { to } 1.20)\end{array}$ & $\begin{array}{c}2 \text { trials, } \\
2060 \text { infants }\end{array}$ \\
\hline \multicolumn{7}{|c|}{ Other neonatal CNS outcomes } \\
\hline IVH & $\begin{array}{c}0.96 \\
(0.86 \text { to } 1.08)\end{array}$ & $\begin{array}{c}4 \text { trials, } \\
4552 \text { infants }\end{array}$ & Not presented & Not presented & $\begin{array}{c}0.96 \\
(0.86 \text { to } 1.08))\end{array}$ & $\begin{array}{c}5 \text { trials, } \\
4552 \text { infants }\end{array}$ \\
\hline Severe IVH (grade 3/4) & $\begin{array}{c}0.83 \\
(0.62 \text { to } 1.13)\end{array}$ & $\begin{array}{c}2 \text { trials, } \\
3699 \text { infants }\end{array}$ & Not presented & Not presented & $\begin{array}{c}0.83 \\
\text { (0.61 to } 1.11)\end{array}$ & $\begin{array}{c}4 \text { trials, } \\
3864 \text { infants }\end{array}$ \\
\hline PVL & $\begin{array}{c}0.93 \\
(0.68 \text { to } 1.28)\end{array}$ & $\begin{array}{c}4 \text { trials, } \\
4552 \text { infants }\end{array}$ & Not presented & Not presented & $\begin{array}{c}0.93 \\
\text { (0.68 to } 1.28)\end{array}$ & $\begin{array}{c}5 \text { trials, } \\
4552 \text { infants }\end{array}$ \\
\hline \multicolumn{7}{|c|}{ Other infant/child neurodevelopmental outcomes } \\
\hline $\begin{array}{l}\text { Developmental delay or } \\
\text { intellectual impairment }\end{array}$ & $\begin{array}{c}0.99 \\
(0.91 \text { to } 1.09)\end{array}$ & $\begin{array}{c}4 \text { trials, } \\
5980 \text { infants }\end{array}$ & Not presented & Not presented & Not presented & Not presented \\
\hline $\begin{array}{l}\text { Major neurological } \\
\text { disability }\end{array}$ & $\begin{array}{c}1.07 \\
(0.82 \text { to } 1.40)\end{array}$ & $\begin{array}{c}2 \text { trials, } \\
2848 \text { infants }\end{array}$ & Not presented & Not presented & $\begin{array}{c}1.09 \\
(0.83 \text { to } 1.43)\end{array}$ & $\begin{array}{c}2 \text { trials, } \\
2060 \text { infants }\end{array}$ \\
\hline Blindness & $\begin{array}{c}0.74 \\
(0.17 \text { to } 3.30)\end{array}$ & $\begin{array}{c}3 \text { trials, } \\
3536 \text { infants }\end{array}$ & Not presented & Not presented & $\begin{array}{c}0.97 \\
(0.14 \text { to } 6.90)\end{array}$ & $\begin{array}{c}2 \text { trials, } \\
1943 \text { infants }\end{array}$ \\
\hline Deafness & $\begin{array}{c}0.79 \\
(0.24 \text { to } 2.56)\end{array}$ & $\begin{array}{c}3 \text { trials, } \\
3536 \text { infants }\end{array}$ & Not presented & Not presented & $\begin{array}{c}0.51 \\
(0.05 \text { to } 4.96)\end{array}$ & $\begin{array}{l}2 \text { trials, } \\
1943 \text { infants }\end{array}$ \\
\hline
\end{tabular}

"moderate-severe CP," and "substantial gross motor dysfunction" (inability to walk without assistance) at 2 years of age. The direction of effect was the same for death or substantial gross motor dysfunction, but this did not reach statistical significance. Results were consistent between trials and across the meta-analyses. Use of magnesium sulphate was not associated with an increase in pediatric death. The tocolytic arm of one study ${ }^{37}$ was stopped early because of an increase in pediatric mortality; although this is consistent with the effects of magnesium sulphate administered as a tocolytic in other studies, ${ }^{34}$ there were other quality issues with the Mittendorf et al. tocolytic arm. These included the confounding effect of multiple births (i.e., more in the magnesium sulphate arm), the low quality score (Jahad score of $2 / 8$ when the other neuroprotective intent trials scored 7-8/8), the lack of a placebo arm, that crossover was allowed, and that 3 of the 8 neonatal deaths in the magnesium sulphate arm were related to congenital anomalies $(n=1)$ or twin-totwin transfusion $(\mathrm{n}=2)$.

When the tocolytic arm of the MAGnet Trial ${ }^{40}$ and results of the preeclampsia prophylaxis trial (MAGPIE) $)^{41}$ were included in the meta-analyses, antenatal magnesium sulphate was shown to reduce the risk of death or moderatesevere $\mathrm{CP}$, any $\mathrm{CP}$, moderate-severe $\mathrm{CP}$, and substantial gross motor dysfunction; the outcome of death or CP no longer reached statistical significance (Table 3b). Although such analyses support the use of magnesium sulphate to decrease CP, the results of the neuroprotective intent trials suggest a change in clinical practice. 
For antenatal magnesium sulphate given specifically for fetal neuroprotection, the NNT to prevent one case of death or $\mathrm{CP}$ is 43 (based on an event rate of $14.9 \%$ overall in the magnesium arm of trials and $17.2 \%$ among placebo-treated controls). The NNT to prevent one case of CP is 63 (based on an event rate of $3.4 \%$ overall in the magnesium arm of the trials and $5.0 \%$ among placebo-treated controls). These compare favourably with other established obstetric interventions, such as the NNT of 50 (95\% CI 34 to 100) for use of magnesium sulphate to prevent eclampsia among women with severe preeclampsia. ${ }^{26}$

While the 3 meta-analyses demonstrate significant results for antenatal magnesium sulphate reducing the risk of death or $\mathrm{CP}$, death or moderate-severe $\mathrm{CP}$, any $\mathrm{CP}$, moderate-severe $\mathrm{CP}$, and substantial gross motor dysfunction at 2 years of age, it is important to note that no single trial demonstrated a statistically significant decrease in the combined outcome of death or CP.

Despite these favourable results, strong evidence is lacking with respect to 4 clinical issues:

1. The gestational age below which this therapy should be offered.

2. The optimal loading and maintenance doses.

3. Antenatal magnesium sulphate has not been associated with a decrease in central nervous system pathology associated with CP, cognitive impairment (i.e., intraventricular hemorrhage or white matter injury measured as cystic periventricular leukomalacia), and other adverse developmental outcomes associated with preterm birth (e.g., developmental delay, neurological impairment, blindness, or deafness). However, confidence intervals in these trials ${ }^{35-38}$ were reasonably wide and compatible with any of the following: a protective effect ( $38 \%$ reduction), harmful effect ( $13 \%$ increase), or no effect at all. Further evidence is needed to determine whether there is an association between magnesium sulphate and decreased CNS pathology.

4. There is no information on the effect of magnesium sulphate on learning disabilities, school difficulties, or other common school-age disabilities, because none of the trials reported on outcomes beyond 2 years of age; follow-up to school-age is planned for 2 of the trials. ${ }^{35,36}$ Neurological follow-up was conducted to the age of 2 years in 3 trials, 2 of which undertook detailed neurocognitive testing. ${ }^{35,38}$ However, learning disabilities and developmental coordination disorder, which are prevalent among extremely low birth weight babies born preterm, cannot be reliably detected until school age.

\section{Recommendations}

2. Although there is controversy about upper gestational age, antenatal magnesium sulphate for fetal neuroprotection should be considered from viability to $\leq 31+6$ weeks. (II-1B)

3. If antenatal magnesium sulphate has been started for fetal neuroprotection, tocolysis should be discontinued. (III-A)

There is some uncertainty about the gestational age at which magnesium sulphate should be administered. A lower gestational age limit for viability has not been specified in these studies ${ }^{35,37}$ so that clinical decisions can take into consideration both parental preference and institutionally defined thresholds. Each of the trials in the meta-analyses ${ }^{32-34}$ had a different upper gestational age limit for study eligibility, ranging from $<30$ weeks $^{35}$ to $\leq 33+6,{ }^{37}$ making it challenging to recommend an upper age limit.

It is uncertain whether the neuroprotective effect of magnesium sulphate depends on gestational age at birth. Table 4a presents the results of trials with neuroprotective intent. The outcome of death or CP was significantly decreased by magnesium sulphate when therapy was administered at $<34$ weeks. The outcome of CP was significantly decreased at all gestational ages. Results for all trials are shown in Table $4 \mathrm{~b}$; the $<30$ week and $<28$ week analyses include post hoc analyses of the MAGPIE and BEAM trials, as randomization was not stratified by these gestational age groupings. No effect of magnesium sulphate was seen on the outcome of death or CP, but CP was significantly decreased at all gestational ages.

There are 2 key considerations when determining a gestational cut-off: (1) the potential for effect modification by gestational age (i.e., the potential for magnesium sulphate to have a different effect at different gestational ages), and (2) the baseline prevalence of $\mathrm{CP}$ at different gestational ages (since the NNT will be lower with a higher baseline prevalence of a disease). Table $4 \mathrm{a}$ (neuroprotective intent trials) and Table $4 \mathrm{~b}$ (all relevant trials) both show that the point estimate for the effect of magnesium sulphate on CP risk reduction appears to be lower at $<28$ weeks. Since the prevalence of $\mathrm{CP}$ is also higher at $<28$ weeks, the NNT to prevent one case of $\mathrm{CP}$ is lowest at $<28$ weeks. The NNT appears to fall for administration of magnesium at earlier gestational ages, with a more obvious trend among all trials rather than among only neuroprotective trials. Regardless, the NNT to prevent one case of CP is low at all gestational ages at $<34$ weeks. 


\begin{tabular}{|c|c|c|c|c|c|}
\hline \multirow[b]{2}{*}{ Weeks } & \multicolumn{2}{|c|}{$\operatorname{RR}(95 \% \mathrm{Cl})$} & \multicolumn{2}{|c|}{ NNT to prevent harm } & \multirow[b]{2}{*}{ Trials, $n$, infants, $n$} \\
\hline & Death or CP & $\mathrm{CP}$ & Death or $\mathrm{CP}$ & $\mathrm{CP}$ & \\
\hline$<34$ & $0.85(0.74$ to 0.98$)$ & 0.71 (0.55 to 0.91$)$ & 43 & 53 & 5 trials, 6145 infants \\
\hline$<32$ & $0.86(0.74$ to 1.00$)$ & $0.68(0.52$ to 0.91$)$ & 43 & 50 & 3 trials, 3981 infants \\
\hline$<30^{*}$ & 0.87 (0.74 to 1.03$)$ & 0.69 (0.48 to 0.99$)$ & 36 & $53 \dagger$ & 3 trials, 2475 infants \\
\hline$<28^{*}$ & $0.95(0.74$ to 1.22$)$ & $0.45(0.23$ to 0.87$)$ & 91 & 30 & 1 trial, 938 infants \\
\hline
\end{tabular}

\begin{tabular}{|c|c|c|c|c|c|}
\hline \multirow[b]{2}{*}{ Weeks } & \multicolumn{2}{|c|}{$\mathrm{RR}(95 \% \mathrm{Cl})$} & \multicolumn{2}{|c|}{ NNT to prevent harm } & \multirow[b]{2}{*}{ Trials, $\mathrm{n}$, infants, $\mathrm{n}$} \\
\hline & Death or CP & $\mathrm{CP}$ & Death or $\mathrm{CP}$ & $\mathrm{CP}$ & \\
\hline$<34$ & 0.94 (0.78 to 1.12$)$ & 0.68 (0.54 to 0.87$)$ & 105 & 63 & 5 trials, 6145 infants \\
\hline$<32$ & 0.95 (0.76 to 1.18$)$ & 0.69 (0.52 to 0.91$)$ & 71 & 56 & 3 trials, 3981 infants \\
\hline$<30^{*}$ & 0.97 (0.78 to 1.21$)$ & 0.70 (0.49 to 0.99$)$ & 71 & $56 \dagger$ & 3 trials, 2475 infants \\
\hline$<28^{*}$ & 0.95 (0.74 to 1.22$)$ & 0.45 (0.23 to 0.87$)$ & 91 & 30 & 1 trial, 938 infants \\
\hline \multicolumn{6}{|c|}{${ }^{*}$ Includes the $<28$ week subgroup of Rouse et al. ${ }^{38}$ which had women as the denominator. } \\
\hline \multicolumn{6}{|c|}{ This also includes the $<30$ week subgroup data provided by the MAGPIE trial. } \\
\hline
\end{tabular}

A more useful post hoc analysis would be to examine CP risk reduction within gestational age strata (32 to 33 weeks, 30 to 31 weeks, 28 to 29 weeks, and $<28$ weeks) to identify the gestational age at which babies may be most likely to benefit. In the BEAM trial, ${ }^{38}$ analyses were stratified by gestational age ( $<28$ vs. 28 to 31 weeks). Although it appeared as if the decrease in CP was confined to the $<28$-week subgroup, the test for interaction by gestational age was actually not significant. This should be interpreted as revealing no difference in magnesium effect on CP rate by gestational age up to $31+6$ weeks. In MAGPIE, ${ }^{41}$ which was not a neuroprotective intent trial and which underreported CP, CP risk was similar at $<30$ weeks (RR 1.04; 95\% CI 0.06 to 16.06 ) and at 30 to 33 weeks (RR $0.95 ; 95 \%$ CI 0.71 to 1.27 ).

In summary, CP risk is highest at earlier gestational ages, but these very preterm infants are fewer in number. Use of magnesium sulphate at gestational ages closer to 34 weeks has the potential to substantially increase overuse of magnesium sulphate for women with threatened preterm birth who do not deliver in the subsequent 24 to 48 hours. Therefore, consensus was reached to recommend an upper gestational age cut-off of $<32$ weeks (i.e., $\leq 31+6$ weeks) to strike a balance between appropriate use of magnesium sulphate at earlier gestational ages and potential overuse of magnesium sulphate at later gestational ages, when neurological morbidity is lower. Institutions may choose different thresholds ( $<34$ weeks) according to other considerations, including the accuracy of gestational age determination and resource allocation.

Table 2 presents the baseline characteristics of women who were enrolled in the relevant randomized controlled trials. In 3 of the 4 neuroprotective intent trials, most women had preterm labour with anticipated delivery within 24 hours. This is not equivalent to threatened preterm labour for which tocolysis is an option in the hope/expectation of being able to arrest labour; this must be emphasized to prevent potential overuse of magnesium sulphate for neuroprotection in patients who are not truly in labour. The other major indications for very preterm delivery (APH or IUGR) were present in a minority of women enrolled in the relevant trials. Although many women also had PPROM, only the BEAM trial ${ }^{38}$ enrolled women with PPROM without associated preterm labour. In this guideline, these women are not included as eligible for magnesium sulphate for neuroprotection. First, in the BEAM trial, retreatment with magnesium was administered for 59.1\% of women. Second, women with PPROM who are not in labour are not necessarily in a delivery suite and receiving one-to-one nursing care; administration of magnesium for neuroprotective intent could have significant hospital resource implications for these women.

All trials excluded women with the usual contraindications to magnesium sulphate (i.e., hypersensitivity to the drug, hepatic 


\begin{tabular}{ll}
\hline $\begin{array}{l}\text { Table 5. Inclusion and exclusion criteria for antenatal } \\
\text { magnesium sulphate administration in randomized } \\
\text { controlled trials }\end{array}$ \\
\hline Inclusion criteria & Exclusion criteria \\
\hline $\begin{array}{l}\text { Singleton and multiple } \\
\text { pregnancies }\end{array}$ & $\begin{array}{l}\text { Magnesium sulphate already } \\
\text { administered for preeclampsia/ } \\
\text { eclampsia } \\
\text { Nulliparous and parous }\end{array}$ \\
$\begin{array}{l}<12 \text { hours since discontinuation } \\
\text { of previous magnesium sulphate } \\
\text { infusion }\end{array}$ \\
$\begin{array}{l}\text { Anticipated vaginal or } \\
\text { Caesarean delivery }\end{array}$ & $\begin{array}{l}\text { Magnesium sulphate } \\
\text { contraindicated }\end{array}$ \\
Any reason for anticipated & Fetus unlikely to benefit \\
preterm birth & \\
\hline
\end{tabular}

coma, myasthenia gravis) and those whose fetus was unlikely to benefit from potential neuroprotection (i.e., severe fetal malformations or chromosomal abnormalities). Antenatal magnesium sulphate for fetal neuroprotection should be used with caution in women who have renal impairment, and serum magnesium levels should be monitored.

Magnesium sulphate for neuroprotection should be administered regardless of singleton or multiple gestation, as women with multiple pregnancies were enrolled in all trials.

The inclusion and exclusion criteria from the published trials are summarized in Table 5.

\section{Recommendations}

4. Magnesium sulphate should be discontinued if delivery is no longer imminent or a maximum of 24 hours of therapy has been administered. (II-2B)

5. For women with imminent preterm birth, antenatal magnesium sulphate for fetal neuroprotection should be administered as a $4 \mathrm{~g}$ IV loading dose, over 30 minutes, followed by a $1 \mathrm{~g} / \mathrm{hr}$ maintenance infusion until birth. (II-2B)

6. For planned preterm birth for fetal or maternal indications, magnesium sulphate should be started, ideally within 4 hours before birth, as a $4 \mathrm{~g} I \mathrm{~V}$ loading dose, over 30 minutes, followed by a $1 \mathrm{~g} / \mathrm{hr}$ maintenance infusion until birth. (II-2B)

As shown in Table 6, 4 trials of magnesium sulphate administered a $4 \mathrm{~g}$ IV loading dose over 20 to $30 \mathrm{~min}^{35-37,41}$ Maintenance dosing varied from none $\mathrm{e}^{36,37}$ to $1 \mathrm{~g} / \mathrm{hr}^{35,41}$ or $2 \mathrm{~g} / \mathrm{hr}^{38}$ for $12 \mathrm{hr}^{38}$ or $24 \mathrm{hr}^{35,41}$ The median dose received was as high as $31.5 \mathrm{~g}$ (IQR of 29.0 to 44.6), but this was the trial primarily of women who had PPROM without labour, and $59.1 \%$ of women were re-treated when delivery was again considered to be imminent. ${ }^{38}$ The median dose was much lower, at $6.5 \mathrm{~g}$ (IQR of 4.5 to $14.0 \mathrm{~g}$ ), ${ }^{35}$ when women were enrolled primarily for preterm labour, reflecting a very short median time from enrolment to delivery.

There have been no direct comparisons of different dosing regimens of magnesium sulphate for neuroprotection. A loading dose of $4 \mathrm{~g}$ IV with a maintenance infusion of $1 \mathrm{~g} / \mathrm{hr}$ has been recommended to (1) resemble current clinical practice and hospital protocols for magnesium sulphate for eclampsia prophylaxis and treatment, and (2) minimize concerns about maternal safety, particularly as higher dosing regimens have not been associated with greater neuroprotection. Trials that administered maintenance infusions treated for a maximum of 24 hours antenatally.

For women with planned preterm birth, for fetal or maternal indications, it is recommended that magnesium sulphate be started as close as possible to 4 hours before birth, as this was the mean time from randomization to birth in subgroup analysis. ${ }^{35}$ No trials randomized women with planned preterm birth to different durations of magnesium sulphate therapy.

Risk of medication errors may be decreased if magnesium sulphate is prepared in the central pharmacy rather than in the labour and delivery suite.

Magnesium sulphate for fetal neuroprotection should be discontinued at delivery.

The one trial (Rouse et $\mathrm{al}^{38}$ ) in which re-treatment was performed enrolled primarily women who had PPROM without labour, and $59.1 \%$ of women were re-treated when delivery was again considered to be imminent. ${ }^{38}$

Magnesium sulphate was infused for neuroprotective intent as quickly as 20 minutes before delivery.

\section{Recommendations}

7. There is insufficient evidence that a repeat course of antenatal magnesium sulphate for fetal neuroprotection should be administered. (III-L)

8. Delivery should not be delayed in order to administer antenatal magnesium sulphate for fetal neuroprotection if there are maternal and/or fetal indications for emergency delivery. (III-E)

9. When magnesium sulphate is given for fetal neuroprotection, maternity care providers should use existing protocols to monitor women who are receiving magnesium sulphate for preeclampsia/ eclampsia. (III-A)

Existing protocols developed for eclampsia prophylaxis and treatment may be used for women given magnesium sulphate for fetal neuroprotection. Close monitoring of 


\section{Magnesium sulphate for fetal neuroprotection in imminent preterm birth $(\leq 31+6$ weeks)}

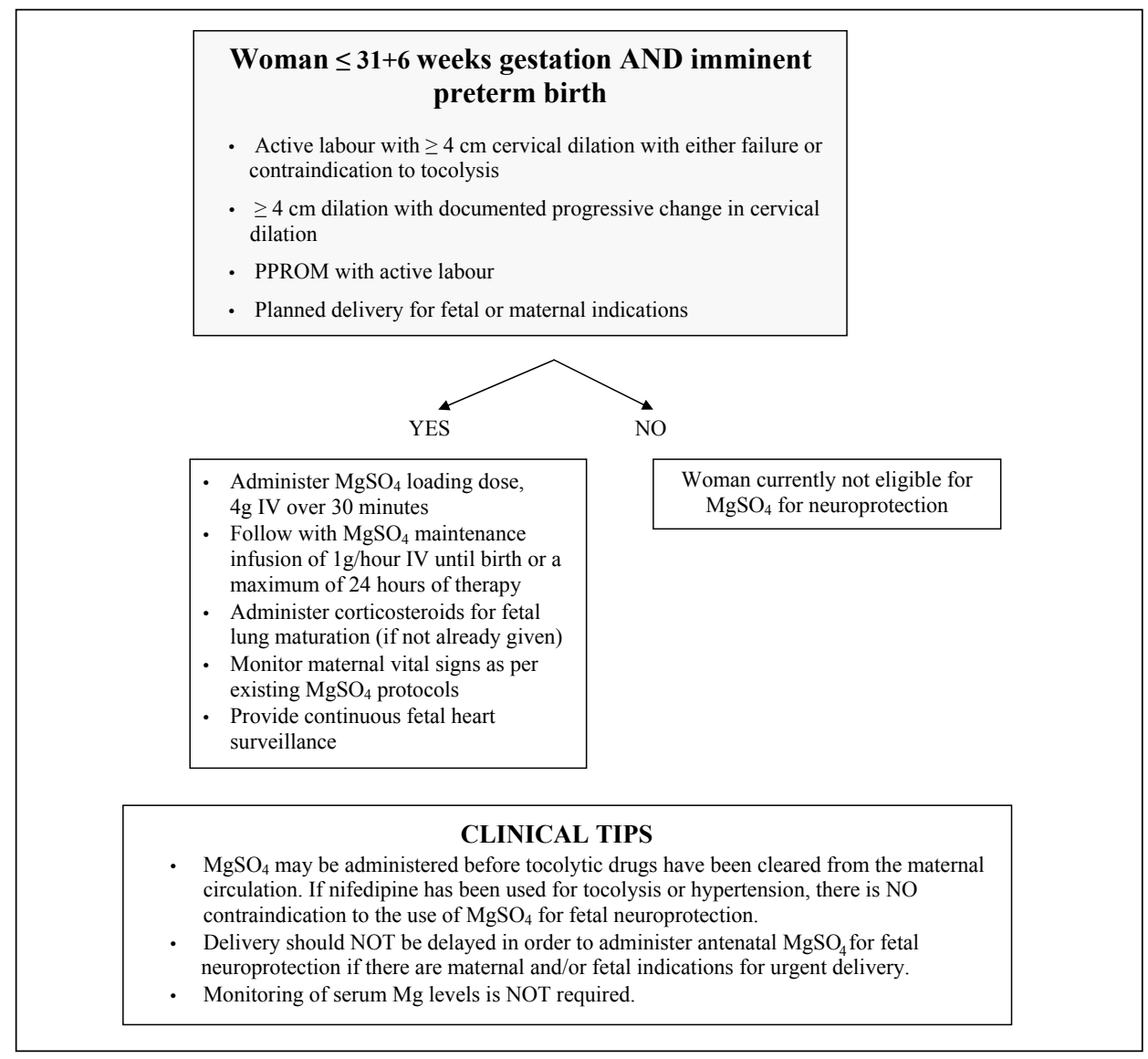

"Imminent preterm birth" is defined as a high likelihood of birth, due to one or both of the following conditions: active labour with $\geq 4 \mathrm{~cm}$ of cervical dilation, with or without PPROM; planned preterm birth for fetal or maternal indications.

maternal urine output should not be required to the same degree (i.e., no requirement for Foley catheter) when magnesium sulphate is given with neuroprotective intent.

Magnesium sulphate produces peripheral vasodilation when infused intravenously. In neuroprotective intent trials, dose-related effects were common, particularly flushing, problems at the injection site, sweating, and nausea and vomiting (Table 7). Serious maternal side effects were uncommon, with only maternal hypotension and tachycardia reaching statistical significance. Few women discontinued magnesium sulphate because of side effects. Neither maternal death nor cardiorespiratory arrest was reported in the magnesium sulphate arm of these trials.

Monitoring of maternal serum magnesium levels is not required when magnesium sulphate is administered solely for fetal neuroprotection. Maternal adverse effects are dose-related, with respiratory or cardiac arrest associated with levels in excess of $5 \mathrm{mmol} / \mathrm{L}$. Levels of this magnitude are not anticipated when magnesium contraindications are observed but are more frequent when magnesium sulphate is prepared in the delivery suite rather than by a central pharmacy.

Because of their underlying condition, women with imminent preterm birth require continuous fetal heart rate monitoring, in accordance with the SOGC fetal health surveillance guidelines. ${ }^{42}$

\section{Recommendations}

10. Indications for fetal heart rate monitoring in women receiving antenatal magnesium sulphate for neuroprotection should follow the fetal surveillance recommendations of the SOGC's 2007 Fetal Health Surveillance: Antepartum and Intrapartum Consensus Guideline. (III-A)

11. Since magnesium sulphate has the potential to alter the neonate's neurological evaluation, causing hypotonia or apnea, health care providers caring for the neonate should have an increased awareness of this effect. (III-C) 


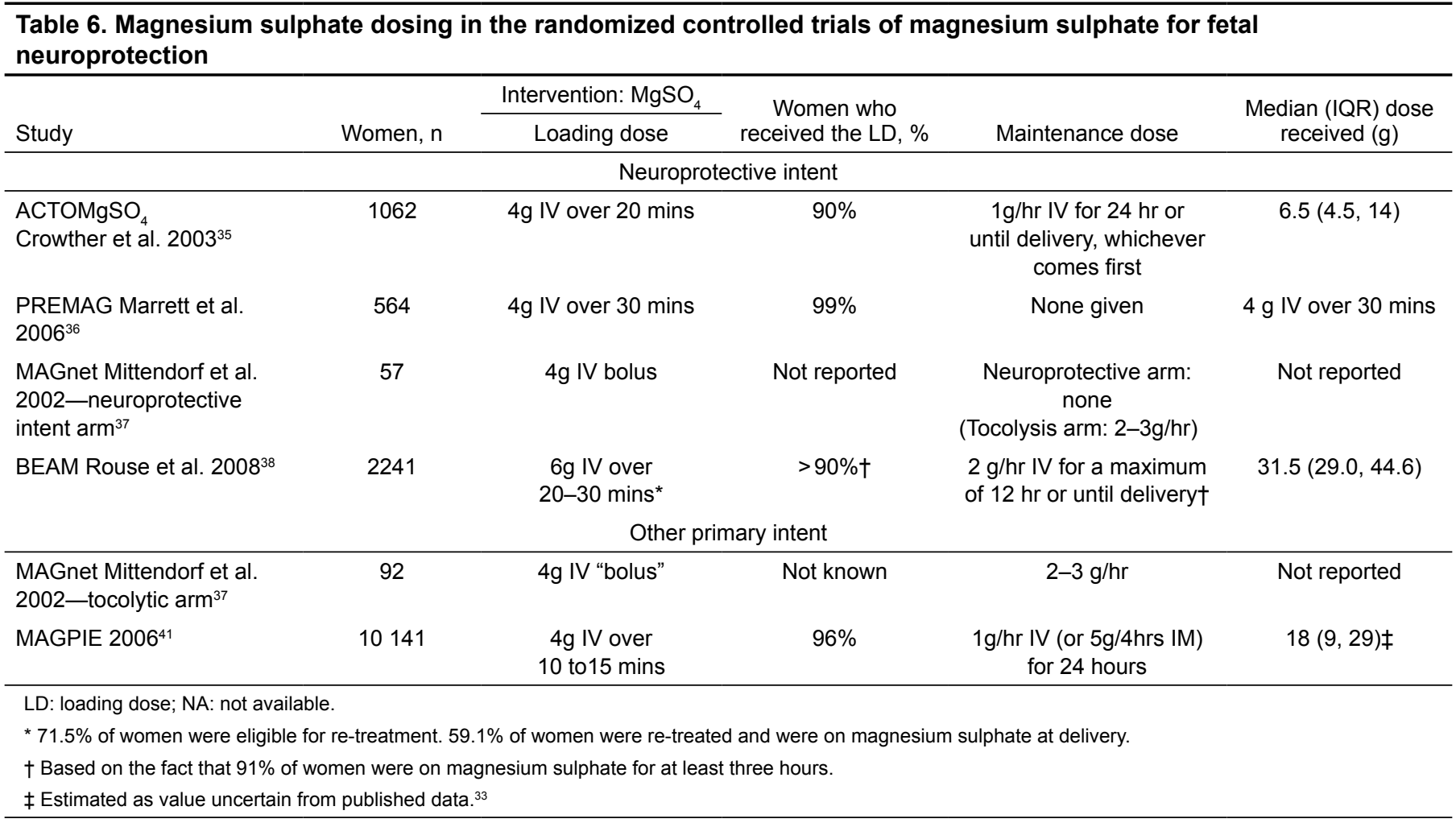

The relevant randomized controlled trials ${ }^{34}$ raise no concerns about short-term neonatal adverse effects of antenatal exposure, and no additional neonatal assessment or care is required. Neonates with hypermagnesemia may present with symptoms of apnea or hypoventilation, weakness, hypotonia, absent or reduced deep tendon reflexes, and stupor or coma. This symptom complex has been described in the neonates of mothers administered large doses of IV magnesium sulphate for eclampsia with neonatal serum levels $>4.5 \mathrm{mEq} / \mathrm{L} .{ }^{43}$ However, antenatal magnesium sulphate administered specifically for fetal neuroprotection did not affect the incidence of Apgar score $<7$ at 5 minutes (RR 1.03; $95 \%$ CI 0.90 to $1.18 ; 3$ trials, 4387 infants), neonatal hypotonia (RR 1.02; 95\% CI 0.77 to 1.36 ; 1 trial, 2444 infants), or the need for ongoing ventilatory support (RR 0.94; 95\% CI 0.89 to 1.00; 3 trials; 4387 women). None of the main trial publications reported on the need for active resuscitation at birth, ${ }^{34}$ but a subanalysis of the BEAM trial found no correlation between cord blood magnesium levels and the need for bag-mask ventilation, intubation, or chest compressions. ${ }^{44}$ It is unknown whether magnesium sulphate exposure would affect the need for ventilation in neonatal intensive care units using protocols to minimize ventilation.

The relevant randomized controlled trials ${ }^{35-38}$ demonstrated no other differences in neonatal morbidity, including seizures, respiratory distress syndrome, bronchopulmonary dysplasia, or necrotizing enterocolitis.
Few newborn subjects with in utero exposure to magnesium sulphate remote from delivery were included in the relevant trials. There is no clear rationale for any additional assessment of these newborns.

There should be an ongoing registry of children exposed to antenatal magnesium sulphate for neuroprotection. This would allow evaluation of the following:

1. Effects on delivery room resuscitation, especially in units with ventilation-avoidance protocols

2. Anticipated reduction in $\mathrm{CP}$

3. Effect on the high prevalence of school age morbidities among infants born preterm.

\section{SPECIAL CONSIDERATIONS REGARDING THE USE OF MAGNESIUM SULPHATE FOR FETAL NEUROPROTECTION}

\section{Transport}

When maternal transport is being considered, magnesium administration should be decided on in consultation with the receiving centre, on a case-by-case basis.

\section{Drug Interactions}

Antenatal corticosteroids should be administered for fetal lung maturation.

When tocolysis has been employed to attempt to arrest preterm labour, magnesium sulphate can be used once 


\begin{tabular}{|c|c|c|c|c|}
\hline & $\begin{array}{c}\mathrm{MgSO}_{4} \\
\mathrm{n}(\%)\end{array}$ & $\begin{array}{c}\text { Placebo } \\
\mathrm{n}(\%)\end{array}$ & $\operatorname{RR}(95 \% \mathrm{Cl})$ & $\begin{array}{c}\text { Trials } \\
\mathrm{n}\end{array}$ \\
\hline \multicolumn{5}{|l|}{ Clinical and self-assessed maternal side effects } \\
\hline Any side effect & $1356 / 1917(70.7)$ & $343 / 1950(17.6)$ & 5.05 (2.06 to 12.39$)$ & 3 \\
\hline \multicolumn{5}{|l|}{ Minor side effects } \\
\hline Flushing & $1119 / 1917(58.4)$ & $162 / 1950(8.3)$ & 7.56 (3.39 to 16.88$)$ & 3 \\
\hline Problems at injection site & $614 / 1631(37.6)$ & $68 / 1672(4.1)$ & $9.12(7.19$ to 11.57$)$ & 2 \\
\hline Sweating & $411 / 1631(25.2)$ & $57 / 1672(3.4)$ & 6.37 (1.96 to 20.68$)$ & 2 \\
\hline Nausea or vomiting & $312 / 1917(16.3)$ & $76 / 1950(3.9)$ & $4.60(1.54$ to 13.75$)$ & 3 \\
\hline \multicolumn{5}{|l|}{ Serious side effects } \\
\hline Hypotension & $80 / 821(9.7)$ & $52 / 805(6.5)$ & 1.51 (1.09 to 2.09$)$ & 2 \\
\hline Tachycardia & $56 / 535(10.5)$ & $36 / 527(6.8)$ & 1.53 (1.03 to 2.29$)$ & 1 \\
\hline Respiratory depression & $41 / 1631(2.5)$ & $31 / 1672(1.9)$ & 1.31 (0.83 to 2.07$)$ & 2 \\
\hline Pulmonary edema & $8 / 1096(0.7)$ & $3 / 1145(0.3)$ & $2.79(0.74$ to 10.47$)$ & 1 \\
\hline Infusion stopped due to adverse effects & $123 / 1631(7.5)$ & $44 / 1672(2.6)$ & 2.81 (2.01 to 3.93$)$ & 2 \\
\hline \multicolumn{5}{|l|}{ Serious maternal adverse effects } \\
\hline Death & 0/1917 & $1 / 1950$ & $0.32(0.01$ to 7.92$)$ & 3 \\
\hline Cardiac or respiratory arrest & 0/1917 & 0/1950 & 一 $^{*}$ & 3 \\
\hline
\end{tabular}

tocolysis has been discontinued because delivery is considered imminent. If nifedipine has been used for tocolysis or hypertension, there is no contraindication to the use of magnesium sulphate for fetal neuroprotection. Although case reports have described neuromuscular blockade with concomitant use of magnesium sulphate and nifedipine or other calcium channel blockers, a controlled study and synthesis of the literature failed to demonstrate an increased risk. ${ }^{42}$

\section{Potential Obstetrical Adverse Outcomes}

In the Conde-Agudelo and Romero meta-analysis, ${ }^{32}$ magnesium sulphate given with neuroprotective intent was not associated with a difference in Caesarean section (822 [42.9\%] in the magnesium arm vs. 834 [42.8\%] for placebo; RR 1.0; $95 \%$ CI 0.9 to $1.1 ; 3$ trials, 3867 women) or severe postpartum hemorrhage (28 [3.4\%] in the magnesium arm vs. $26[3.2 \%$ for placebo; RR 1.1; 95\% CI 0.6 to 1.8 ; 2 trials, 1626 women). None of the trials reported on length of labour or augmentation of labour.

\section{CLINICAL PRACTICE GUIDELINES AND COMMITTEE OPINION}

Australian National Clinical Practice Guidelines ${ }^{45}$ were published in March 2010 by the Antenatal Magnesium Sulphate for Neuroprotection Guideline Development Panel. They recommended antenatal magnesium sulphate for fetal neuroprotection (excellent evidence) in the same dosage as recommended in these guidelines. However, magnesium was recommended only at $<30$ weeks' gestation (good evidence) on the basis of two considerations. First, no one gestational age subgroup (of the $<34,<33,<32$, and $<30$ week categories considered) was considered to show a clear benefit, although the $<28$ week subgroup of Rouse et al. ${ }^{38}$ was not included, because the committee felt that the predominance of PPROM in that study population limited generalizability to the target population of women with imminent preterm labour (which the committee defined as planned or definitely expected within 24 hours). Second, in the face of uncertainty, the committee felt it was prudent to limit the impact of their clinical practice guidelines on resource allocation.

Also in March 2010, the American College of Obstetricians and Gynecologists issued a committee opinion on magnesium sulphate for fetal neuroprotection. It stated that "the available evidence suggests that magnesium sulphate given before anticipated early preterm birth reduces the risk of cerebral palsy in surviving infants." No official opinion was given on a gestational age cut-off, but it was recommended that physicians develop specific guidelines around the issues of inclusion criteria, dosage, concurrent tocolysis, and monitoring in accordance with one of the larger trials. ${ }^{46}$ 


\section{REFERENCES}

1. Public Health Agency of Canada. Canadian Perinatal Health Report. Ottawa: Minister of Public Works and Government Services Canada, 2008.

2. Woodward LJ, Anderson PJ, Austin NC, Howard K, Inder TE. Neonatal MRI to predict neurodevelopmental outcomes in preterm infants. N Engl J Med 2006;355:685-94.

3. Anderson P, Doyle LW. Neurobehavioral outcomes of school-age children born extremely low birth weight or very preterm in the 1990s. JAMA 2003;289:3264-72.

4. Kuban KC, Leviton A. Cerebral palsy. N Engl J Med 1994;330:188-95.

5. Center for Disease Control and Prevention. What is cerebral palsy? Available at: http://www.cdc.gov/ncbddd/dd/ddcp.htm. Accessed March 3, 2011.

6. Vincer MJ, Allen AC, Joseph KS, Stinson DA, Scott H, Wood E. Increasing prevalence of cerebral palsy among very preterm infants: a population-based study. Pediatrics 2006;118(6):e1621-e1626.

7. Petrini JR, Dias T, McCormick MC, Massolo ML, Green NS, Escobar GJ. Increased risk of adverse neurological development for late preterm infants. J Pediatr 2009;154:169-76.

8. Moster D, Lie RT, Markestad T. Long-term medical and social consequences of preterm birth. N Engl J Med 2008;359:262-73.

9. Stanley FJ. Survival and cerebral palsy in low birthweight infants: implications for perinatal care. Paediatr Perinat Epidemiol 1992;6:298-310.

10. Drummond PM, Colver AF. Analysis by gestational age of cerebral palsy in singleton births in north-east England 1970-94. Paediatr Perinat Epidemiol 2002;16:172-80.

11. Pharoah PO, Cooke T, Johnson MA, King R, Mutch L. Epidemiology of cerebral palsy in England and Scotland, 1984-9. Arch Dis Child Fetal Neonatal Ed 1998;79(1):F21-F25.

12. Winter S, Autry A, Boyle C, Yeargin-Allsopp M. Trends in the prevalence of cerebral palsy in a population-based study. Pediatrics 2002;110(6):1220-5.

13. Petterson B, Nelson KB, Watson L, Stanley F. Twins, triplets, and cerebral palsy in births in Western Australia in the 1980s. BMJ 1993;307(6914):1239-43.

14. Hack M, Costello DW. Trends in the rates of cerebral palsy associated with neonatal intensive care of preterm children. Clin Obstet Gynecol 2008;51:763-74.

15. Robertson CM, Watt MJ, Yasui Y. Changes in the prevalence of cerebral palsy for children born very prematurely within a population-based program over 30 years. JAMA 2007;297(24):2733-40.

16. Hagberg B, Hagberg G, Beckung E, Uvebrant P. Changing panorama of cerebral palsy in Sweden. VIII. Prevalence and origin in the birth year period 1991-94. Acta Paediatr 2001;90:271-7.

17. Economic costs associated with mental retardation, cerebral palsy, hearing loss, and vision impairment-United States, 2003. MMWR Morb Mortal Wkly Rep 2004;53:57-9.

18. Leviton A, Kuban KC, Pagano M, Brown ER, Krishnamoorthy KS, Allred EN. Maternal toxemia and neonatal germinal matrix hemorrhage in intubated infants less than 1751 g. Obstet Gynecol 1988;72:571-6.

19. Van de B or [Van de Bor M, ] M, Verloove-Vanhorick SP, Brand R, Keirse $\mathrm{MJ}$, Ruys JH. Incidence and prediction of periventricular-intraventricular hemorrhage in very preterm infants. J Perinat Med 1987;15:333-9.

20. Nelson KB, Grether JK. Can magnesium sulfate reduce the risk of cerebral palsy in very low birthweight infants? Pediatrics 1995; 95:263-9.

21. Grether JK, Cummins SK, Nelson KB. The California Cerebral Palsy Project. Paediatr Perinat Epidemiol 1992;6:339-51.
22. Kuban KC, Leviton A, Pagano M, Fenton T, Strassfeld R, Wolff M. Maternal toxemia is associated with reduced incidence of germinal matrix hemorrhage in premature babies. J Child Neurol 1992;7:70-6.

23. Grether JK, Hoogstrate J, Walsh-Greene E, Nelson KB. Magnesium sulfate for tocolysis and risk of spastic cerebral palsy in premature children born to women without preeclampsia. Am J Obstet Gynecol 2000;183:717-25.

24. O'Shea TM, Klinepeter KL, Dillard RG. Prenatal events and the risk of cerebral palsy in very low birth weight infants. Am J Epidemiol 1998;147:362-9.

25. Schendel DE, Berg CJ, Yeargin-Allsopp M, Boyle CA, Decoufle P. Prenatal magnesium sulfate exposure and the risk for cerebral palsy or mental retardation among very low-birth-weight children aged 3 to 5 years. JAMA 1996;276:1805-10.

26. Altman D, Carroli G, Duley L, Farrell B, Moodley J, Neilson J, et al. Do women with pre-eclampsia, and their babies, benefit from magnesium sulphate? The Magpie Trial: a randomised placebo-controlled trial. Lancet 2002;359(9321):1877-90.

27. Duley L, Carroli G, Belizan J, Gonzalez L, Campodonico L, Bergel, E et al. Which anticonvulsant for women with eclampsia—evidence from the Collaborative Eclampsia Trial. Lancet 1995;345(8963):1455-63.

28. Gathwala G. Neuronal protection with magnesium. Indian J Pediatr 2001;68:417-9.

29. Nelson KB, Grether JK. Causes of cerebral palsy. Curr Opin Pediatr 1999;11:487-91.

30. Burd I, Breen K, Friedman A, Chai J, Elovitz MA. Magnesium sulfate reduces inflammation-associated brain injury in fetal mice. Am J Obstet Gynecol 2010;202:292-9.

31. McDonald JW, Silverstein FS, Johnston MV. Magnesium reduces $\mathrm{N}$-methyl-D-aspartate (NMDA)-mediated brain injury in perinatal rats. Neurosci Lett 1990;109(1-2):234-8.

32. Conde-Agudelo A, Romero R. Antenatal magnesium sulfate for the prevention of cerebral palsy in preterm infants less than 34 weeks' gestation: a systematic review and metaanalysis. Am J Obstet Gynecol 2009;200:595-609.

33. Costantine MM, Weiner SJ. Effects of antenatal exposure to magnesium sulfate on neuroprotection and mortality in preterm infants: a metaanalysis. Obstet Gynecol 2009;114(2 Pt 1):354-64.

34. Doyle LW, Crowther CA, Middleton P, Marret S, Rouse D. Magnesium sulphate for women at risk of preterm birth for neuroprotection of the fetus. Cochrane Database Syst Rev 2009;(1):CD004661.

35. Crowther CA, Hiller JE, Doyle LW, Haslam RR. Effect of magnesium sulfate given for neuroprotection before preterm birth: a randomized controlled trial. JAMA 2003; 290(20):2669-76.

36. Marret S, Marpeau L, Zupan-Simunek V, Eurin D, Leveque C, Hellot $\mathrm{MF}$, et al. Magnesium sulphate given before very-preterm birth to protect infant brain: the randomised controlled PREMAG trial*. BJOG 2007;114:310-8.

37. Mittendorf R, Dambrosia J, Pryde PG, Lee KS, Gianopoulos JG, Besinger $\mathrm{RE}$, et al. Association between the use of antenatal magnesium sulfate in preterm labor and adverse health outcomes in infants. Am J Obstet Gynecol 2002;186:1111-8.

38. Rouse DJ, Hirtz DG, Thom E, Varner MW, Spong CY, Mercer BM, et al. A randomized, controlled trial of magnesium sulfate for the prevention of cerebral palsy. N Engl J Med 2008; 359(9):895-905.

39. Magee LA, Helewa M, Rey E, Cote AM, Douglas J, Gibson P, et al. Diagnosis, evaluation, and management of the hypertensive disorders of pregnancy. SOGC Clinical Practice Guideline no. 206, March 2008. J Obstet Gynaecol Can 2008;30(Suppl 1):S1-S48. 
40. Mittendorf R, Covert R, Boman J, Khoshnood B, Lee KS, Siegler M. Is tocolytic magnesium sulphate associated with increased total paediatric mortality? Lancet 1997;350(9090):1517-8.

41. The Magpie Trial: a randomised trial comparing magnesium sulphate with placebo for pre-eclampsia. Outcome for children at 18 months. BJOG 2007;114:289-99.

42. Liston R, Sawchuck D, Young D; SOGC Fetal Health Surveillance Consensus Committee. Fetal health surveillance: antepartum and intrapartum consensus guideline. SOGC clinical practice guideline no. 197, September 2007. J Obstet Gynaecol Can 2007;29(Suppl 4):S1-S58.

43. Volpe JJ. Neurology of the newborn. 4th ed. Philadelphia: W.B. Saunders; 2001.

44. Johnson L; for the Eunice Kennedy Shriver, National Institute of Child Health and Human Development Maternal Fetal Medicine Units Network,
Bethesda MD. Correlation of cord blood magnesium level with neonatal resuscitation requirements in preterm infants. Presented at: Pediatric Academic Societies Meeting; May 2010; Vancouver BC.

45. The Antenatal Magnesium Sulphate for Neuroprotection Guideline Development Panel. Antenatal magnesium sulphate prior to preterm birth for neuroprotection of the fetus, infant and child: national clinical practice guidelines. The Australian Research Centre for Health of Women and Babies, The University of Adelaide; 2010.

46. Magee LA, Miremadi S, Li J, Cheng C, Ensom MH, Carleton B, et al. Therapy with both magnesium sulfate and nifedipine does not increase the risk of serious magnesium-related maternal side effects in women with preeclampsia. Am J Obstet Gynecol 2005;193:153-63.

47. Woolf SH, Battista RN, Angerson GM, Logan AG, Eel W. Canadian Task Force on Preventive Health Care. New grades for recommendations from the Canadian Task Force on Preventive Health Care. CMAJ 2003;169:207-8. 